\title{
Immunological and Protein Chemical \\ Comparison of Ovotransferrin \\ between Birds
}

\author{
Soichi Tsuji, Etsuko Uchitani, and Toyokazu Fukushima \\ Faculty of Agriculture, Kobe University, Kobe 657, Japan
}

(Received March 22, 1985)

\begin{abstract}
Ovotransferrin (OTf) was purified from different species of birds by two different methods; one using CM- and DEAE-Sephadex column chromatography, and the other using immuno-adsorbent column chromatography. By both methods, OTf was purified as a single protein from albumen of chicken, quail, duck, and pigeon. The molecular weight of OTf of chicken, quail, duck, and pigeon are 77500, 75100, 76400, and 77500 , respectively when measured by sodiumdodecylsulfate polyacrylamide gel electrophoresis (SDS-PAGE). A double immuno-diffusion test showed that precipitin lines of purified OTf and transferrin (Tf) of each bird fused together on an agar gel with chicken OTf antiserum, while the lines between different birds showed a spur pattern. This result shows high similarity of OTf and $\mathrm{Tf}$ within a species. Single radial immunodiffusion tests and immunoadsorbent column chromatography showed the content of OTf in albumen of chicken, quail, duck, and pigeon to be $12.37 \pm 0.20 \%, 11.20 \pm 0.60 \%$, $1.61 \pm 0.63 \%$, and $13.04 \pm 1.30 \%$, respectively. These OTfs and Tfs, purified by using an immuno-adsorbent column, were shown to be a single polypeptide on SDS-PAGE, suggesting that both OTf and Tf do not show the moleculer weight heterogeneity observed in bovine $\mathrm{Tf}$.

Jpn. J. Zootech. Sci., 56 (10): 807-815, 1985

Key word: ovotransferrin, transferrin, birds, immunoadsorbent, heterogeneity
\end{abstract}

Transferrin (Tf), one of the iron binding proteins, has been intensively studied in the field of animal genetics,2). It is well known that in many animals each $\mathrm{Tf}$ variant shows electrophoretic heterogeneity due to a different number of sialyl residues being attached to the molecule. Another cause of heterogeneity appeared in cattle Tf, which consists of two polypeptides of different molecular weight ${ }^{3}$. Complexes of bovine Tf antibodies and Tfs have been analyzed to clarify whether the molecular weight heterogeneity is general in Tf molecules of different species ${ }^{4}$. However, cattle fetus and ruminants other than cattle did not show molecular weight heterogeneity of Tf. Sera of non-ruminants or birds were not tested because of the high specificity of the antiserum which reacts with neither non-ruminant nor bird Tf.

There are two well known proteins related to $\mathrm{Tf}$, lactoferrin and ovo-transferrin (OTf). In chicken the latter is the same protein as $\mathrm{Tf}$ when some sugar moieties are eliminated ${ }^{5}$. As sugar moieties have a marginal effect on the antigenicity of the protein to which they are attached, an antibody against chicken OTf may have broad immuno-reactivity against many OTfs and Tfs from different birds. In this study we investigated whether molecular weight heterogeneity is present or not in OTf or Tf of birds using chicken OTf antiserum. Additionally, some new evidence concerning 
OTfs of different birds is described.

\section{Materials and Methods}

\section{Materials}

Eggs and blood serum of White Leghorn chicken, Osaka duck, Japanese quail, and domestic pigeon were used in this study. Blood serum of duck and quail were kindly provided by Professor Y. Tanabe and Dr. S. Itoh, respectively, both of Gifu University.

\section{Polyacrylamide gel electrophoresis}

Polyacrylamide gel electrophoresis (PAGE) and sodium dodecylsulfate polyacrylamide gel electrophoresis (SDS-PAGE) were carried out as described by GAHNE et al. () $^{\text {) }}$ and LAEMMLI"), respectively; details are shown in our previous paper ${ }^{4)}$. The gel of SDS-PAGE or, PAGE was stained with $0.1 \%$ Coomassie Brilliant Blue R 250 and destained with $5 \%$ acetic acid at $70^{\circ} \mathrm{C}$ for 3 to $5 \mathrm{hr}$.

Molecular weight standards which were used on SDS-PAGE were RNA polymerase $\alpha, \alpha^{\prime}$, and $\beta$ subunit $(\mathrm{Mr}=165000,155000$, and 39000$)$, and bovine serum albumin $(\mathrm{Mr}=68000)$ purchased from Behringer Manheim.

\section{Ovo-transferrin antibodies}

To obtain chicken OTf antiserum from rabbits, each animal was injected five times at weekly intervals with $1 \mathrm{~m} l$ of a mixture which contained an equal volume of purified OTf (10 mg) and Freund's complete adjuvant (Difco Chem.). The purification method of chicken OTf is described in the 'Results and Discussion'.

Double immuno-diffusion tests were performed using the OTf antiserum in $1 \%$ agar gel containing $0.1 \mathrm{M}$ potassium phosphate buffered saline, $\mathrm{pH}$ 7.0.

Immuno-electrophoresis was carried out in an agar gel; details are shown in the legend of Fig. 2.

Concentration of OTf in egg albumen was determined by single radial immunodiffusion tests using chicken OTf antiserum. The authentic curve for calibration of OTf content in each egg albumen was made using purified chicken OTf.

Immuno-adsorbent column chromatography was also used to determine the OTf content of eggs, and the Tf content of serum of different species. The OTf antibodies were purified as follows; three $\mathrm{ml}$ of the antiserum was thoroughly mixed with the same volume of saturated ammonium sulfate solution at $4^{\circ} \mathrm{C}$ for $20 \mathrm{~min}$. Then the precipitate, centrifuged at $10,000 \mathrm{~g}$ for $10 \mathrm{~min}$, was dialyzed overnight against $0.01 \mathrm{M}$ sodium phosphate buffer, $\mathrm{pH}$ 7.2. The dialyzed solution was applied to a DEAEcellulose (Whatman, DE 32) column ( 1 by $25 \mathrm{~cm}$ ) equilibrated with the buffer, and non-adsorbed fractions of immuno-globulin G (IgG) were collected, concentrated, and dialyzed against $0.1 \mathrm{M} \mathrm{Na}$-bicarbonate buffer, $\mathrm{pH} 9.0$. The IgG fraction, $30 \mathrm{mg}$ of IgG, was coupled with $1 \mathrm{~g}$ of cyanogen bromide activated Sepharose $4 \mathrm{~B}$ gel according to the recommended method of the manufacturer (Pharmacia Fine Chem). The swollen gel, about $4 \mathrm{ml}$, can bind $1.7 \mathrm{mg}$ of chicken OTf. 
Protein concentrations were measured by the method of Lowry et al. ${ }^{8}$, using bovine serum albumin as a standard.

\section{Results and Discussion}

\section{Purification of ovotransferrin from eggs of different birds}

Purification methods of OTf from egg albumen of chicken, quail, duck have been developed by several workers.10,11) using combinations of the following steps: ethanol precipitation, acid precipitation, ammonium sulfate fractionation, DEAE- and CMcellulose column chromatography and gel filtration. These methods are different from each other, so that it seems difficult to prepare OTf from albumen of different birds by using only one of these methods. We present here two simple methods suitable for OTf purification from egg albumen of different birds.

Egg albumen was diluted with an equal volume of distilled water to reduce the viscosity. Solid ammonium sulfate was added to a final concentration of $30 \%$ saturation, and stirred for $40 \mathrm{~min}$ at $4^{\circ} \mathrm{C}$. Then it was centrifuged at $10000 \mathrm{rpm}$ for $10 \mathrm{~min}$ and the precipitate was discarded. The supernatant layer was dialyzed overnight against tap water. One hundredth part by volume of $1 \mathrm{M} \mathrm{Na}$-Citrate, $\mathrm{pH} 5.0$ was added to the solution and applied to a column of CM-Sephadex C $50(1.8$ by $20 \mathrm{~cm})$ previously equilibrated with $0.01 \mathrm{M} \mathrm{Na}$-citrate buffer, pH 5.0. To eliminate nonadsorbed proteins, the column was washed with the buffer until absorbance at $280 \mathrm{~nm}$ reached less than 0.01 . Then the OTf was eluted by linear gradient from 0.01 to $0.1 \mathrm{M} \mathrm{Na}$-citrate, $\mathrm{pH} \mathrm{5.0.} \mathrm{The} \mathrm{fractions} \mathrm{containing} \mathrm{OTf} \mathrm{were} \mathrm{collected} \mathrm{and} \mathrm{concen-}$ trated using a rotary vacuum evaporator, and dialyzed against $0.05 \mathrm{M}$ Tris- $\mathrm{HCl}, \mathrm{pH}$ 8. 0 . The solution containing OTf was applied to a column of DEAE-Sephadex A 50 $(1.8$ by $20 \mathrm{~cm}$ ) equilibrated with $0.05 \mathrm{M}$ Tris- $\mathrm{HCl}$ buffer, $\mathrm{pH} 8.0$. Adsorbed OTf was eluted by a linear gradient of $\mathrm{NaCl}$ from 0 to $0.2 \mathrm{M}$ dissolved in the buffer. The fractions containing OTf were collected, dialyzed against distilled water and lyophilized.

In Fig. 1, a single protein band is detectable in each column of OTf from different birds on a SDS-PAGE. This result shows that OTf can be purified from albumen of chicken, quail, duck, and pigeon using the simple method above described. The yields of OTf from egg albumen of chicken, quail, duck, and pigeon were $9.7 \%$, $9.4 \%, 2.1 \%$, and $15.4 \%$, respectively. As chicken egg albumen actually contains $12 \%$ OTf $^{12)}$, the recovery rate is high $(80.8 \%)$. As shown later, using immunoadsorbent column chromatography OTf content of hen albumen was $12.4 \%$, which is consistent with the value obtained by FEENEY et al. ${ }^{12}$. Therefore, this simple OTf purification method also has a high recovery rate. Egg albumen contains a different amount of OTf from bird to bird; the highest is $15 \%$ in pigeon and the lowest is $2.5 \%$ in duck. This result is further confirmed by single radial immuno-diffusion test and by immuno-adsorbent column chromatography as stated later. Molecular weights of OTf of chicken, quail, duck, and pigeon were estimated as 77500, 75100, 76400 , and 77500, respectively, using molecular weight standards on SDS-PAGE. IToH et al. ${ }^{10)}$ reported that the molecular weight of quail OTf is 76000 , the same as 


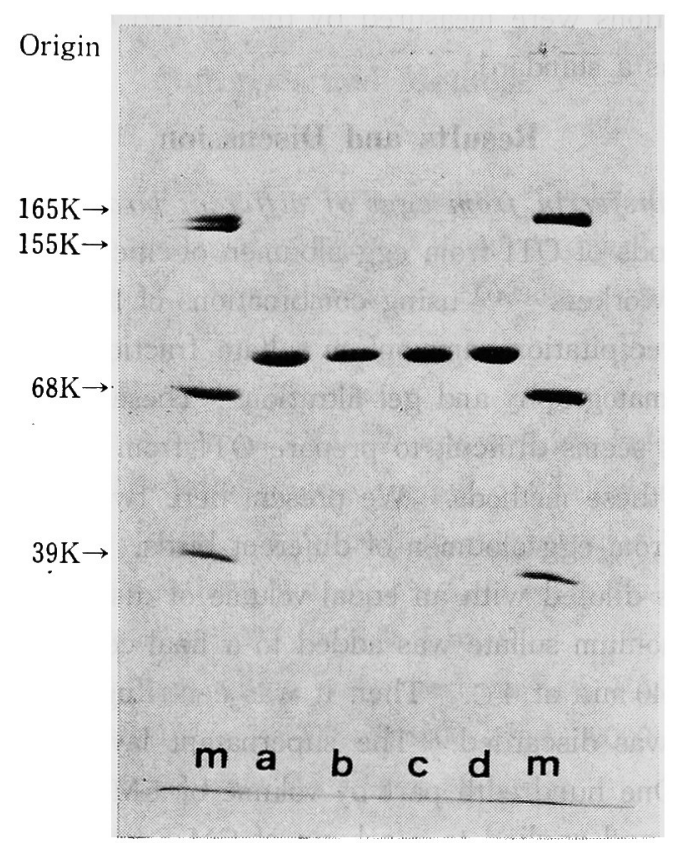

Fig. 1. SDS-polyacrylamide gel electrophoresis of purified ovotransferrins (OTfs) from albumen of different birds; $m$ : marker proteins, a: quail OTf, b: duck OTf, c: pigeon OTf, and d: chick OTf. Each purified OTf contained about $3 \mu \mathrm{g}$ protein. Left margin shows the molecular weight $(\times 1000=\mathrm{K})$ of marker proteins.

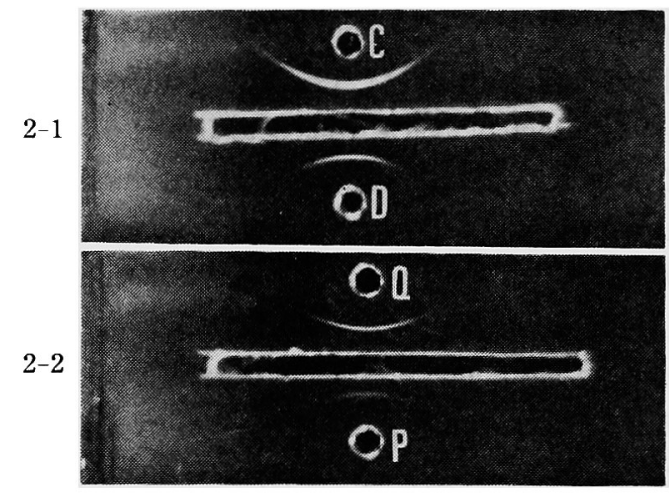

Fig. 2. Immuno-electrophoresis of purified ovotransferrins (OTfs) of different birds on $1 \%$ agar gel containing $0.05 \mathrm{M}$ veronal buffer, $\mathrm{pH}$ 8.6. Electrophoresis was performed at $2 \mathrm{~mA}$ per $\mathrm{cm}$ for $1 \mathrm{hr}$. Each well containned $20 \mu \mathrm{g}$ of OTfs: C: chick OTf, D: duck OTf, Q: quail OTf, and P: pigeon OTf and the center ditches contained $0.1 \mathrm{ml}$ of chicken OTf antiserum.

that of chicken OTf ${ }^{13}$, by gel filtration analysis. The values presented here are slightly lower than those presented by Iтон et al. ${ }^{10)}$ and GREene and FeEneY ${ }^{13}$. The difference in molecular weight may be due to different methods being used for molecular 
weight calibration. As shown in Fig. 2, immuno-electrophoresis of purified OTt showed a single precipitin arc. This also suggests that each purified OTf is a single protein.

From this result, it is suggested that in birds, OTf consists of a single polypeptide of about 76000 dalton, thus differing from cattle Tf which consists of two polypeptides of different molecular weight, 78000 and 72000 dalton.

\section{Immunological comparisons}

Figs 3-a and 3-b show the results of double immuno-diffusion tests which were conducted to compare the immuno-reactivity of purified OTfs. Precipitin lines between OTfs and Tfs of different species show clear spur formation with somewhat different intensity of the lines between species. That of pigeon OTf and Tf were es-

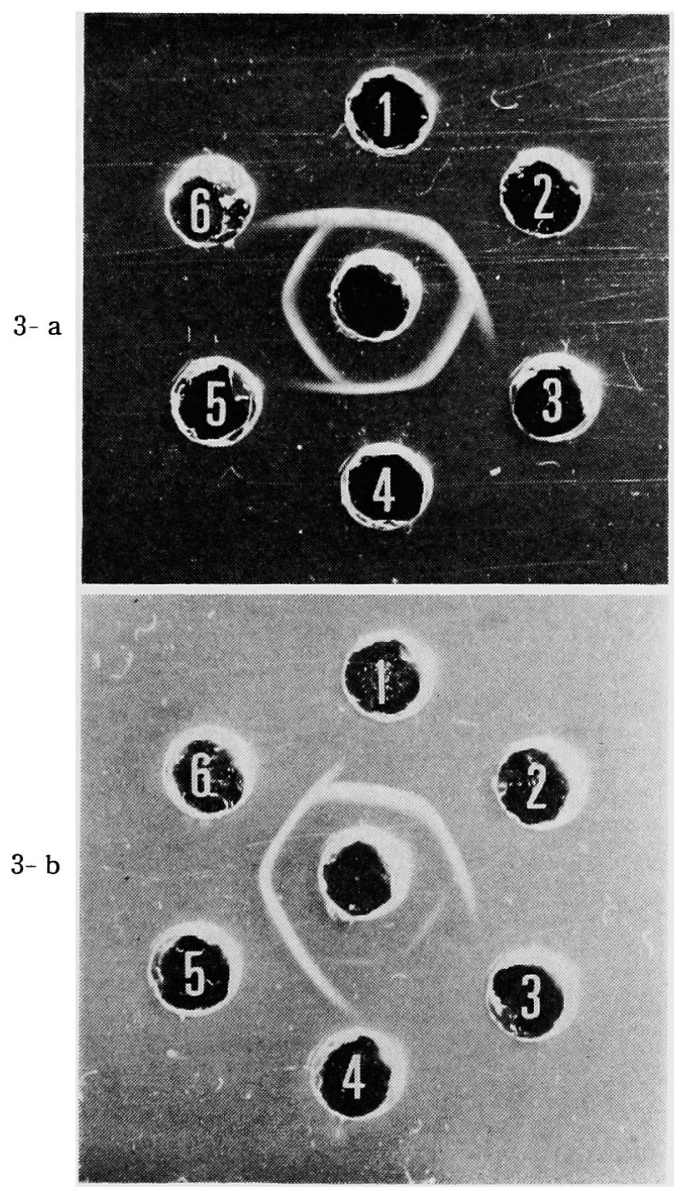

Fig. 3. Double immuno-diffusion test of ovotransferrins (OTfs) and transferrins ( $\mathrm{Tfs}$ ) using antiserum against purified chicken OTf. The center well contained antiserum and the wells are; $3-\mathrm{a} ; 1$ : chicken OTf, 2 : chicken serum, 3: quail OTf, 4: quail serum, 5: duck OTf. 6: duck serum, 3-b; 1: duck OTf, 2: duck serum, 3: pigeon OTf, 4: pigeon serum, 5: chicken OTf, 6: chicken serum. 
pecially poor. The lines of OTf and Tf of a given species showed a pattern of fusion. A similar result, a spur formation between duck and chicken OTf using duck OTf antiserum, has been reported by DAS ${ }^{11}$. It is suggested that $\mathrm{Tf}$ is the same protein as OTf, except for minor differences in sugar moieties, and is synthesized in the liver and excreted into egg albumen with slight modifications in the sugar chains ${ }^{9)}$. As the differences in sugar moieties between OTf and Tf in chicken are restricted to sialic acid and hexose content, it seems likely that they do not affect the antigenicity of OTf and Tf of chicken.

Using a single radial immuno-diffusion test, the content of OTf in egg albumen of chicken and quail were estimated. The value for chicken albumen is $92.8 \pm 6.65$ mg per egg, and is $13.2 \pm 0.95 \%$ of total albumen protein, while the value for quail is $10.72 \pm 0.72 \mathrm{mg}$ per egg and is $11.5 \pm 0.76 \%$. This result also showed that chicken and quail eggs contain a similar amount of OTf in their albumen. However, OTf content in duck and pigeon albumen could not be measured using a single radial im. muno-diffusion test due to their lower immuno-reactivity with chicken OTf antiserum. Thus, we determined not only the OTf content of duck and pigeon albumen, but also the Tf content in sera of the four species of birds using immuno-adsorbent column

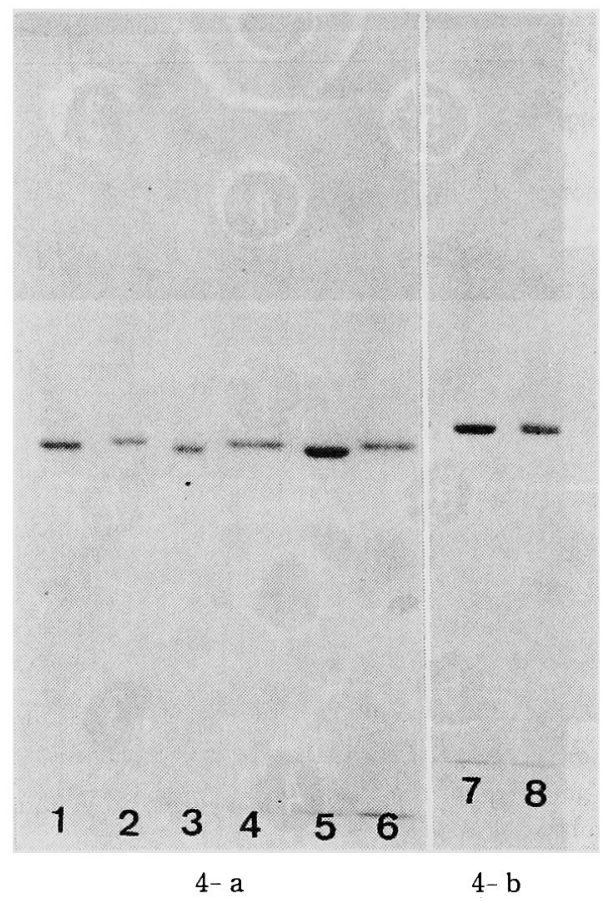

Fig. 4. SDS-polyacrylamide gel electrophoresis of ovotransferrins (OTfs) and transferrins (Tfs) purified using immuno-adsorbent column chromatography. 4-a; 1: chicken OTf, 2: chicken Tf, 3: quail OTf, 4: quail Tf, 5: duck OTf, 6: duck Tf, and 4-b; 7: pigeon OTf, 8: pigeon Tf. Each OTf or Tf loaded was about $2 \mu \mathrm{g}$. 
chromatography.

Diluted blood serum or egg albumen $(5 \mathrm{mg}$ protein $/ \mathrm{ml}$ ) which contained less than $1.7 \mathrm{mg}$ of OTf or Tf was applied to the column of immuno-adsorbent chromatogram $(0.8$ by $5 \mathrm{~cm})$. After washing the column with $0.05 \mathrm{M} \mathrm{Na}$-bicarbonate buffer, $\mathrm{pH}$ 8.0 until absorbance at $280 \mathrm{~nm}$ of eluant reached less than 0.01 , bound OTf or Tf was eluted with $1 \mathrm{M}$ acetic acid. The eluant, containing protein, was lyophilized.

Figs 4-a and 4-b show the proteins eluted from the immuno-adsorbent column. Each lane shows a single protein of OTf or Tf on SDS-PAGE. Using the column, therefore, OTf or Tf can be purified quite easily as a single protein. Each OTf and Tf appears as a single polypeptide, in accordance with the result obtained from purified OTfs. This result also suggested that both OTf and Tf in birds do not display molecular weight heterogeneity. The amount of OTf in albumen was estimated using the column; the values for chicken, quail, duck, and pigeon were $12.37 \pm 0.20 \%$, $11.2 \pm 0.63 \%, 1.61 \pm 0.63 \%$, and $13.3 \pm 1.3 \%$, respectively. The values for chicken and quail are consistent with those as measured by a single radial immuno-diffusion test. Comparing the mobilities of OTf and Tf of each bird, OTf moved faster than Tf on SDS-PAGE, which suggests that OTf is smaller than Tf. As WiLlams report$\mathrm{ed}^{9)}$, Tf contains more carbohydrates, ( $2 \%$ more hexose and $0.35 \%$ more sialic acid) than OTf in chicken, so the molecular weight of OTf should be smaller than that of Tf, if OTf and Tf have the same polypeptide domain. The transferrin content of

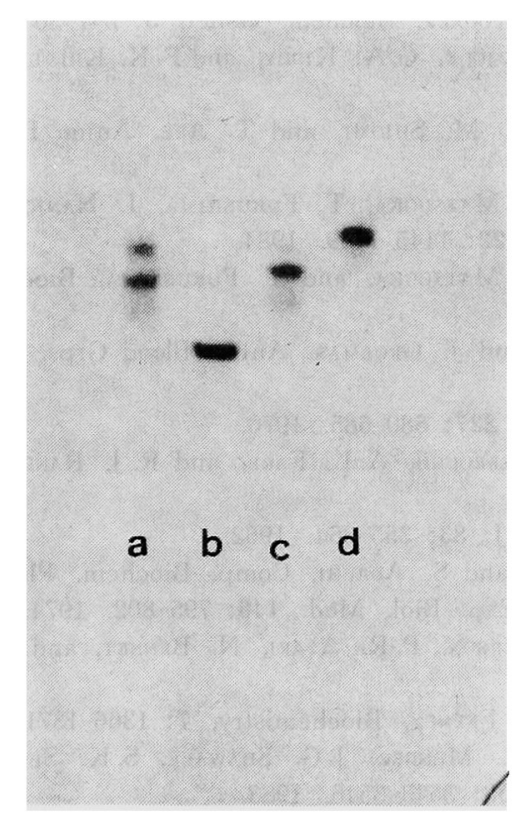

Fig. 5. Polyacrylamide gel electrophoresis of purified ovotransferrins (OTfs) from albumen of different birds; a: pigeon OTf, b: duck OTf, c: quail OTf, and d: chicken OTf. About $2 \mu \mathrm{g}$ of OTf were loaded. 
chicken, quail, duck, and pigeon are about $1.41,0.35,0.46$, and $0.53 \mathrm{mg}$ per $\mathrm{m} l$ of serum, respectively.

In Fig. 5, purified OTfs from different birds were electrophoresed on PAGE. Only pigeon OTf displayed electrophoretic heterogeneity, showing two major bands and one minor band. As pigeon OTf consists of a single polypeptide as cited above, it seems likely that the multiple bands of pigeon OTf are due to a different number of sialic acids being attached to the molecule or due to genetic variants in the albumen.

In this paper, we described two methods of OTf purification; one using CMand DEAE-Sehadex, and the other using immuno-adsorbent column chromatography. In both methods, purified OTfs could be obtained quite easily from egg albumen of different birds. Using the latter method, serum Tf from different birds could also be purified. Both OTf and Tf of different birds consist of a single polypeptide of about 76,000 dalton. Our previous report showed that bovine Tf shows molecular weight heterogeneity with two polypeptides of different molecular weight and among ruminants the phenomenon seemed to be limited to cattle ${ }^{4}$. Bearing in mind that human and rat $\mathrm{TfS}^{14,15)}$, which are well comprehended, also consist of a single polypeptide, the results obtained here from OTfs and Tfs of birds support the supposition that molecular weight heterogeneity of $\mathrm{Tf}$ is limited to cattle.

\section{References}

1) Stratil, A. and R. L. Spooner, Biochem. Genet. 5: 347-365. 1971.

2) Ashton, G. C., D. G. Gilmour, C. A. Kidox, and F. K. Kristjansson, Genetics 56: 353-362. 1967.

3) Tsuji, S., T. Fukushima, M. Shromi, and T. Aвe, Anim. Blood Grps and biochem. Gent. 12: 299-305. 1981 .

4) Tsuji, S., H. Kato, Y. Matsuoka, T. Fukushima, I. Nanjoh, T. Amano, and T. NamiKAwA, Biochem. Genet. 22: 1145-1159. 1984.

5) Tsuji, S., H. Kato, Y. Matsuoka, and T. Fukushima, Biochem. Genet. 22: 1127-1143. 1984.

6) Gahne, B., R. Juneja, and J. Grolmas, Anim. Blood Grps. biochem. Genet, 8: 127-137. 1977.

7) Laemml, U. K., Nature. 227: 680-685. 1970.

8) Lowry, O. H., N. J. Rosebrough, A. L. Farr, and R. J. Randall, J. Biol. Chem. 193: 265275. 1951.

9) Williams, J., Biochem. J., 83: 355-364. 1962.

10) Itoh, T., H. Sugahara, and S. Adachi, Comp. Biochem. Physiol. 62 B: 41-44. 1979.

11) Das, B. R., Proc. Soc. Exp. Biol. Med., 146: 795-802. 1974.

12) Feeney, R. E., J. S. Anderson, P. R. Azari, N. Bennet, and M. B. Rhodes, J. Biol. Chem. 235: 2307-2311, 1960.

13) Greene, F. C., and R. E. Feeney, Biochemistry, 7: 1366-1371. 1968.

14) MacGillivray, R. I. A., E. Mendez, J. G. Shawale, S. K. Sinha, J. Lineback-Zins, and K. Brew, J. Biol. Chem. 258: 3543-3546. 1983

15) Schreiber, G., H. Dryburch, A. Millership, Y. Matsuda, A. Inglis, J. Phillips, K. Edwards, and J. Maggs, J. Biol. Chem. 254: 12013-12017. 1979. 


\title{
種を異にするオボトランスフェリンの比較
}

\author{
过荘一・内谷悦子・福島豊一
}

神戸大学费学部, 神戸怰 657

ウシ血清トランスフェリンは分子量の異なる2つのボ リペプチドから成っている，一力，血清トランスフェリ ンと同様に鉄結合能を持つ糖蛋白質オボトランスフェリ ンが鳥類の即白中に存在する、本研究では, 数種の鳥類 の瞅白からオボトランスフェリンを精製し，ウシ血清ト ランスフェリンK沶いて見られる上記現象が鳥類のオボ トランスフェリンや血清トランスフェリンに拈いても見

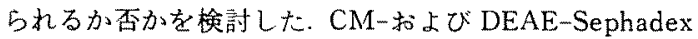
カラムクロマトグラフィーを用いる方法と免疫吸着カラ ムクロマトグラフィ一法によって異種の鳥類(ニワトリ， ウズラ、アヒル，八ト）の莭白からオボトランスフェリ ンを精製した．いずれの方法でも買種の莭白からオボト ランスフェリンが単一の分子として得られた.このオボ
トランスフェリンをSDS-PAGEによって分析したとこ ろ，いずれ子単一の分子量のbののみで，その分子量は ニワトリ77,500, ウズラ 75,100, アヒル76,500, 八卜 77,500であって，ウシで楒められるよ5な分子量の変異 性はなかった。同一種内のオボトランスフェリンとトラ ンスフェリンとは高い免疫類似性を示したが，異種間で は顕著な差異があった，単円拡散法と免疫吸着カラムク ロマトグラフィー法により求めた畉白中のオボトランス フェリン量, はニワトリ $12.4 \pm 0.6 \%$ ， ウズラ $11.2 \pm$

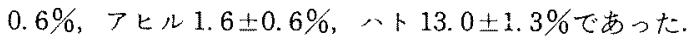
アヒルの值が特に低い。

日畜会報，56(10)：807-815，1985 


\title{
Influence of High Altitude Environment \\ on the Autonomic Nervous Function of \\ Cattle Estimated by the Responses to \\ Auricular Stimulation in RR Interval \\ and Blood Glucose
}

\author{
Yuji Takemura, Hisashi Hirose and Shigeru Sugano \\ Department of Animal Environmental Physiology, \\ Faculty of Agriculture, The University of Tokyo, \\ Bunkyo-ku, Tokyo 113
}

(Received April 11, 1985)

\begin{abstract}
In this study, we tried to elucidate how the autonomic nervous function of the cattle changes at high altitude based on the appearance of the somato-autonomic reactions observed in the responses of $R R$ interval and blood glucose to a mechanical stimulation to the auricle. Sixty-six head of Japanese black cattle raised all the year at high altitude $(1070-1230 \mathrm{~m})$ and fifty-three at low altitude $(40 \mathrm{~m})$ were examined (named highland and lowland cattle, respectively). The auricular stimulation produced tachycardiac and hyperglycaemic responses in general. In the lowland cattle, significant correlations $(p<0.05)$ between resting level and the change due to stimulation in both $R R$ interval and blood glucose were recognized in young cattle (under 2 years old) but not in old cattle ( 2 years old and over). On the contrary, in the highland cattle, significant correlations were not recognized in young cattle but in old cattle. The reactivities to the stimulation were generally larger in the highland cattle than in the lowland cattle, and this tendency was more clearly observed in young cattle than in old cattle. It was considered from the results that the autonomic nervous function of animals was altered to adaptate to a high altitude environment and would be stabilized after the facilitation in the sympathetic nervous activity. Jpn. $J$. Zootech. Sci., 56 (10): 816-821, 1985

Key word: high altitude, autonomic function, cattle, RR interval, blood glucose
\end{abstract}

A high altitude environment affects greatly the cardiopulmonary function of animals $^{1,2)}$, and the low oxygen tension of the air is considered to be the most influential environmental factor for the changes in its function ${ }^{3,4}$. We suggested in our recent report ${ }^{5)}$ that the autonomic nervous function of animals was also affected by a high altitude environment. For the physiological understanding of the changes in the cardiopulmonary function, it is considered very important to know the contribution of the autonomic nervous system, because it plays a regulatory role in the function. In both man and animals, the autonomic nervous function is often estimated by observing the reflex responses ${ }^{6,7}$. In thi sstudy, we estimated the autonomic nervous function of the cattle based on the appearance of the somato-autonomic reactions ${ }^{8)}$ observed in the responses of $R R$ interval and blood glucose to a mechanical stimulation to the auricle, and tried to elucidate how the autonomic nervous function of animals changes at high altitude. 


\section{Materials and Methods}

Examinations were carried out in the summer of 1984 on the herds of Japanese black cattle raised all the year at low and high altitudes (named lowland and highland cattle, respectively). Sixty-six head of the cattle raised at $1070-1230 \mathrm{~m}$ in altitude at the Alpine Region Branch of National Grassland Institute, Ministry of Agriculture, Forestry and Fisheries (Miyota-machi, Kitasaku-gun, Nagano Pref.) were used as the highland cattle. The animals were divided into 2 groups according to their ages (young age group: 30 head, under 2 years old; and old age group: 36 head, 2 years old and over) for estimating the changes in the autonomic nervous function with the prolongatiton of residence at high altitude. Fifty-three head of the cattle raised at $40 \mathrm{~m}$ in altitude at the Ibaraki Prefectural Experimental Station of Animal Husbandry (Tomobe-machi, Nishiibaraki-gun, Ibaraki Pref.) were used as the lowland cattle (41 head, under 2 years old; and 12 head, 2 years old and over).

Animals were confined in a chute in a standing position. A mechanical stimulation to the auricle was produced by nipping with a pair of cattle nose tongs (Ushihanakanshi-SK type, Fujihirakogyo Co. ) for 20 seconds. Electrocardiogram was recorded continuously for 1 minute including pre- and post-stimulation periods (10 and 30 seconds, respectively). Blood sample was collected from the jugular vein at resting state and 3 minutes after the onset of the stimulation.

$\mathrm{RR}$ intrerval at resting state (the mean value during the pre-stimulation period) and the change due to the stimulation ( $\Delta R R=$ minimum $R R$ interval during the stimulation period minus that of the resting state) were calculated from the measurements in the electrocardiogram. Blood glucose was measured by an oxidase method with a blood analyzer (RaBA-super system, Chugai Pharmaceutical Co.) using the blood plasma centrifuged at $3,000 \mathrm{rpm}$ for 10 minutes, and the change in blood glucose value ( $\Delta \mathrm{BG}=$ the value after stimulation minus that of the resting state) was obtained.

\section{Results}

The values of $R R$ interval and blood glucose at resting state and the changes due to the auricular stimulation are shown in Table 1 . The auricular stimulation by nipp-

Table 1. Resting values and the changes due to auricular stimulation in $R R$ interval and blood glucose (Means \pm S. D.)

\begin{tabular}{|c|c|c|c|c|c|c|}
\hline & & \multicolumn{3}{|c|}{ young age group } & \multicolumn{2}{|c|}{ old age group } \\
\hline & & $L(n=41)$ & & $H(n=30)$ & $L(n=12)$ & $H(n=36)$ \\
\hline RR interval & msec & $572.2 \pm 67.4$ & $*$ & $671.8 \pm 87.7$ & $753.2 \pm 219.4^{\mathrm{a}}$ & $642.3 \pm 112.9$ \\
\hline$\triangle \mathrm{RR}$ & msec & $-38.1 \pm 31.9$ & $*$ & $-83.5 \pm 67.4$ & $-70.0 \pm 57.7$ & $-81.7 \pm 62.1$ \\
\hline blood glucose & $\mathrm{mg} / \mathrm{d} l$ & $61.4 \pm 7.1$ & $*$ & $71.3 \pm 9.9$ & $51.7 \pm 10.6^{a}$ & $54.0 \pm 5.3^{3}$ \\
\hline$\triangle B G$ & $\mathrm{mg} / \mathrm{d} l$ & $1.5 \pm 4.5$ & & $1.2 \pm 4.7$ & $7.2 \pm 6.2^{\mathrm{a}}$ & $4.7 \pm 4.5^{\mathrm{a}}$ \\
\hline
\end{tabular}

$\triangle \mathrm{RR}, \triangle \mathrm{BG}$ : changes in $\mathrm{RR}$ interval and blood glucose, respectively. $\mathrm{H}$ : highland cattle. L: lowland cattle. *: significant difference between lowland and highland cattle $(\mathrm{p}<0.05)$. a: significant difference between young and old age groups $(p<0.05)$. 
Table 2. Correlation between resting value and the change due to auricular stimulation in RR interval and blood glucose

\begin{tabular}{cccccc}
\hline \hline & \multicolumn{2}{c}{ young age group } & & \multicolumn{2}{c}{ old age group } \\
\cline { 2 - 3 } & $\mathrm{L}(\mathrm{n}=41)$ & $\mathrm{H}(\mathrm{n}=30)$ & $\mathrm{L}(\mathrm{n}=12)$ & $\mathrm{H}(\mathrm{n}=36)$ \\
\hline $\begin{array}{c}\text { RR interval } \\
\text { correlation coefficient } \\
\text { significance }\end{array}$ & -0.4959 & -0.1125 & -0.2563 & -0.5887 \\
$\begin{array}{c}\text { Blood glucose } \\
\text { correlation coefficient } \\
\text { significance }\end{array}$ & $\mathrm{S}$ & $\mathrm{N}$ & $\mathrm{N}$ & $\mathrm{S}$ \\
\hline
\end{tabular}

$H$ : highland cattle. L: lowland cattle. S: significant $(\mathbf{p}<0.05) . \quad N$ : not significant.

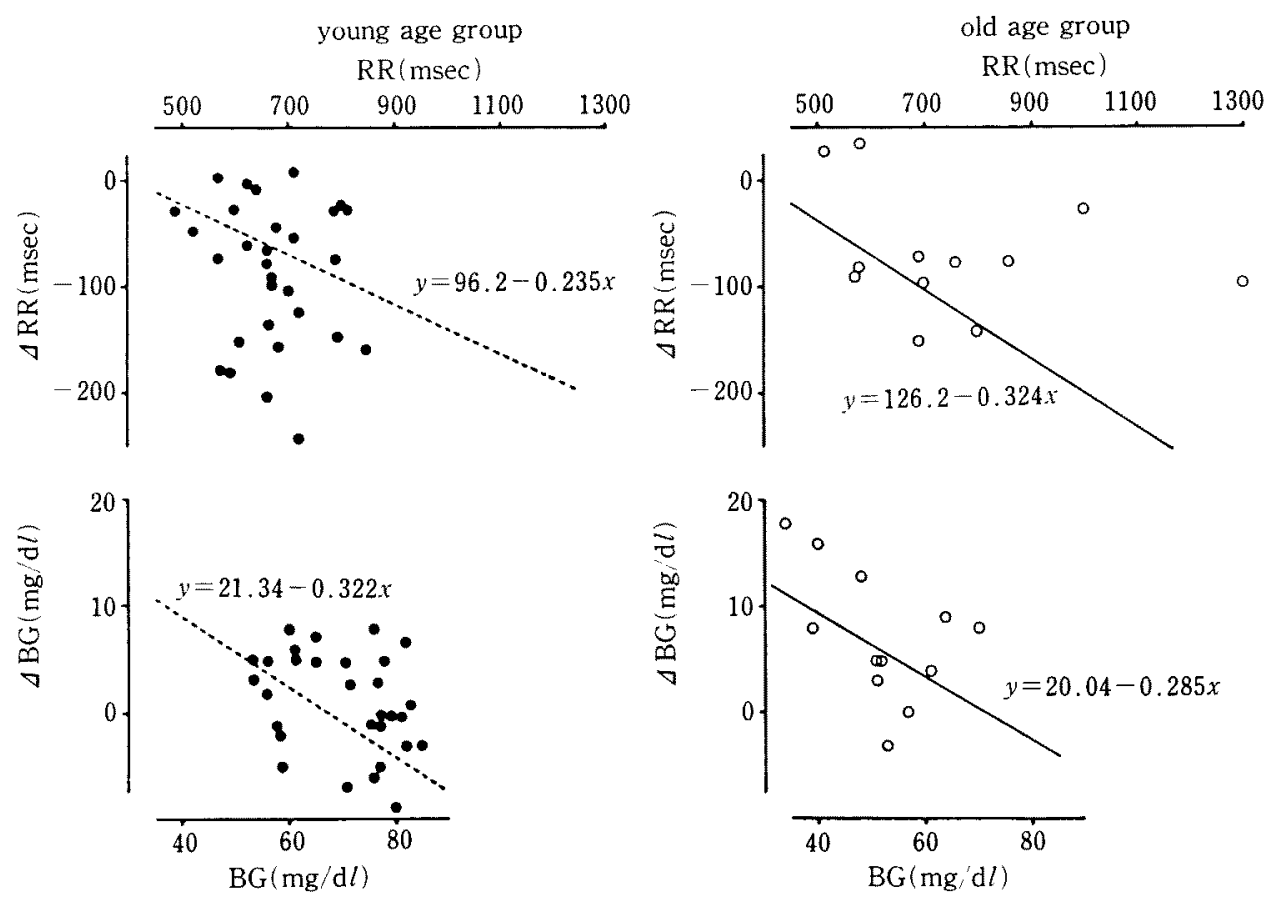

Fig. 1. Correlation chart of resting value and the change due to auricular stimulation in RR interval and blood glucose. $R R, B G$ : resting values of $R R$ interval and blood glucose, respectively. $\triangle \mathrm{RR}, \triangle \mathrm{BG}$ : changes in $\mathrm{RR}$ interval and blood glucose, respectively. $\bullet$ : highland cattle. $O$ : lowland cattle. Solid line: regression line of highland cattle. Broken line: regression line of lowland cattle. The data of the cattle groups which showed the significant correlations between resting values and the changes were represented by the regression lines. By comparing the numbers of plots on both sides of the regression line, it was revealed that the reactivity to the auricular stimulation in RR interval was larger in the highland cattle than in the lowland cattle in both young and old age groups. The large reactivity to the auricular stimulation of the highland cattle was also observed in blood glucose in young age group but not in old age group.

ing produced tachycardiac and hyperglycaemic responses in general, as they were indicated by the minus mean value of the change in RR interval and the plus mean value of the change in blood glucose. 
Table 2 shows the correlation of resting value and the change due to the auricular stimulation in RR interval and blood glucose. In the lowland cattle, significant correlations in both $\mathrm{RR}$ interval and blood glucose were recognized in young age group but not in old age group. In the highland cattle, however, significant correlations were not recognized in young age group but in old age group.

The reactivities to the auricular stimulation in $\mathrm{RR}$ interval and blood glucose were compared between the lowland and the highland cattle in correlation charts (Fig. 1). From Fig. 1, it was revealed that the reactivities to the auricular stimulation were larger in the highland cattle than in the lowland cattle in general, and this tendency was more clearly observed in young age group than in old age group.

\section{Discussion}

In recent years, the physiological mechanism of somato-autonomic reaction has been studied intensively.9,10). It is revealed in several investigations that a mechanical stimulation to the skin such as pinching with forceps or rubbing with a brush produces several kinds of somato-autonomic reactions, e.g., somato-cardiac ${ }^{11.12}$, -gastric ${ }^{13)}$, -intestinal ${ }^{14}$ and -adrenal ${ }^{15)}$ reactions. In this study, the mechanical stimulation to the auricle by nipping with tongs was employed for producing somato-autonomic reactions.

The sympathetic and the vagal nerves are known to contribute to the heart rate changes produced by the stimulation to the $\operatorname{skin}^{(1)}$ or to the cutaneous nerves ${ }^{16)}$. It was reported that a reflex increase in heart rate evoked by the stimulation to the skin was produced mainly by a reflex increase in the discharges of the cardiac sympathetic efferent nerves and partially by a reflex decrease in the discharges of the cardiac vagal efferent nerves ${ }^{12)}$. Although there are few reports about the changes in blood glucose produced by the stimulation to the skin or to the somatic afferent fibers, it is known that the stimulation to the skin influences the activities of the splanchnic and the vagal nerve fibers ${ }^{13,14,15)}$. It is reported that the electronical stimulation of the splanchnic nerve produces an increase in blood glucose in many kinds of domestic animals including cattle ${ }^{17,18,19}$. On the other hand, no or little effect of the vagal stimulation on the blood glucose was reported in baboon ${ }^{20)}$ or cattle ${ }^{21}$. It can be considered that the tachycardiac and hyperglycaemic responses to the auricular stimulation were produced mainly by the evoked excitation of the sympathetic nervous system.

In the highland cattle, significant correlations between resting value and the change in both RR interval and blood glucose were not observed in young age group but in old age group. This result of the highland cattle was in clear contrast with that of the lowland cattle. Thus the appearance of the somato-autonomic reactions of the highland cattle was revealed to be different from that of the lowland cattle. It was suggested from the result that a high altitude environment affected the function of the autonomic nervous system of animals.

It is well known that the activation in the sympathetic nervous system accelerates the cardiopulmonary function. Therefore, the facilitation in the cardiopulmonary func- 
tion observed in the animals when exposed to natural ${ }^{1.2)}$ or simulated ${ }^{3,22}$ high altitudes is considered to be closely related to the facilitation in the sympathetic nervous activity.

In this study, the tachycardiac and hyperglycaemic responses to the auricular stimulation were considered to be mediated mainly by the sympathetic nervous system. Moreover, it was observed that the reactivities to the stimulation of the highland cattle were greater than those of the lowland cattle in general, and this tendency was clearer in young age group than in old age group. It was presumed, therefore, that the activity of the sympathetic nervous system was facilitated by a high altitude environment especially at the early stage of residence at high altitude.

We presumed in our previous report ${ }^{4}$, based on the observations of the cardiopulmonary changes during the six weeks exposure to a simulated high altitude in rats, that the physiological conditions of animals altered with residential stage to achieve a new stable condition as the process of adaptation to a high altitude environment. By comparing with the lowland cattle, the highland cattle showed the significantly large resting values of RR interval and blood glucose only in young age group, and the large reactivities to the stimulation were more clearly observed in young age group than in old age group. In this study, therefore, alterations with residential stage in the physiological conditions including the autonomic nervous system were also considered to be taken place as the process of adaptation to a high altitude environment.

From the results obtained in this study, it was considered that the autonomic nervous function of animals was altered to adaptate to a high altitude environment and would be stabilized after the facilitation in the sympathetic nervous activity.

\section{Acknowledgements}

We are much grateful to the director and the staff of the Alpine Region Branch of National Grassland Institute and also of the Ibaraki Prefectural Experimental Station of Animal Husbandry for their kind offering of the use of the animals and their help for this investigation.

\section{References}

1) Sawazaki, H., Jpn. J. Zootech. Sci., 44: 451-459. 1973.

2) Vogel, J. A. and J. P. Hannon, J. Appl. Physiol, 21: 1595-1601. 1966.

3) Takemura, Y., S. Sugano, H. Hirose and H. Sawazaki, Jpn. J. Zootech. Sci., 54: 755757. 1983.

4) Takemura, Y., S. Sugano, H. Hirose and H. Sawazaki, Jpn. J. Zootech. Sci., 55: 508-514. 1984.

5) Sugano, S., H. Hirose, Y. Takemura, H. Matsumoto, R. Furukawa and Y. Kariya, Jpn. J. Zootech. Sci., 56: 306-311, 1985. (in Japanese)

6) Takeshita, A., S. Tanaka, A. Kurolwa and M. Nakamura, Circ., 51: 738-742. 1975.

7) Slinker, B. K., K. B. Campbell, J. E. Alexander and P. A. Klavano, Am. J. Vet. Res., 43: 1926-1933. 1982.

8) Sato, A., The Autonomic Nervous System, 15: 88-96. 1978. (in Japanese)

9) Sato, A. and R. F. Schmidt, Physiol. Rev., 53: 916-947. 1973. 
10) Terui, N. and K. Kolzum1, J. Auton. Nerv. Syst., 10: 73-91. 1984.

11) Sato, A., Y. Sato, F. Shimada and Y. Torigata, Brain Res., 110: 301-311. 1976.

12) Kaufman, A., A. Sato, Y. Sato and H. Sugrmoto, Neuroscience, 2: 103-109. 1977.

13) Kametani, H., A. Sato, Y. Sato and A. Simpson, J. Physiol. (Lond. ), 294: 407-418. 1979.

14) Kolzumı, K., A. Sato and N. Terul, Brain Res., 182: 85-97. 1980.

15) Araki, T., K. Ito, M. Kurosawa and A. Sato, Neuroscience, 12: 289-299. 1984.

16) Norman, J. and J. G. Whitwam, J. Physiol. (Lond. ), 234: 89 P-90 P. 1973.

17) Edwagos, A. V., J. Physiol. (Lond. ), 213: 741-759. 1971.

18) Järhult, J., P. -O. Andersson, J. Holst, E. Moghimzadeh and A. Nobin, Acta Physiol. Scand, 110: 5-11. 1980.

19) Bloon, S. R., A. V. Edwards and M. A. Ghatel, J. Physiol. (Lond.), 346: 519-531. 1984.

20) Daniel, P.M. and J.R. Henderson, J. Physiol. (Lond.), 192: 317-327. 1967.

21) Adrian, T.E., S. R. Bloom and A. V. Edwards, J. Physiol. (Lond.), 344: 25-35. 1983.

22) Bianca, W. and F. L. Hays, Int. J. Biometeor., 19: 155-165. 1975.

\title{
体性自律神経反応から見た牛の自律神経機能に 対する高地環境の影響
}

\author{
竹村勇司・広瀬恋・菅野茂 \\ 東京大学農学部, 東宗都交京区 113
}

\begin{abstract}
牛の自律神経機能が高地環境下でどのように変化する のかを，耳介に機械的刺激を加えた時に心電図 RR 間隔 および血糖值の変化に観察される体性自律神経反応に基 ついて䛿べた。

黒毛和種を对象にして，標高 1070 1230 $\mathrm{m}$ の高地で 常時飼責されている 66 頭 (高地牛) と標高 $40 \mathrm{~m}$ の低地

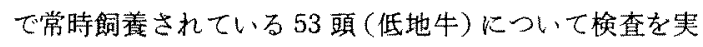
施した。
\end{abstract}

耳介刺激に対し，概ね， RR 間隔は減少，血糖值は上 昇を示した，低地牛では，RR 間隔・血糖值とす安静時
レベルと刺激に対する变化量との間に有意 $(\mathrm{P}<0.05)$ な相関関係が，2才未满で認められたが，2才以上では 認められなかった。これに対して，高地牛では，相関は 2 才未满では認められず，2才以上で㤎められた。刺激 に対する反応性は，高地物が低地牛より名概して大きく， 特に2才未満でこの傾向が顕著であった。

以上の成結から，動物の自律神程機能促，高地環境に 適応して変化し，交感神経系の活動性の元進をへて安定 した状態に至るものと考えられた。

日盲会報, $56(10): 816-821,1985$ 